\title{
Factors Influencing Airborne Conidial Concentrations of Alternaria panax in Cultivated American Ginseng Gardens
}

\author{
S. N. Hill, Graduate Research Assistant, and M. K. Hausbeck, Professor, Department of Plant Pathology, Michigan \\ State University, East Lansing, MI 48824
}

\begin{abstract}
Hill, S. N., and Hausbeck, M. K. 2009. Factors influencing airborne conidial concentrations of Alternaria panax in cultivated American ginseng gardens. Plant Dis. 93:1311-1316.

Leaf blight, caused by Alternaria panax, is the most common disease of cultivated ginseng and is an annual threat. To determine the influence of weather parameters on airborne conidial concentrations (ACCs), 3- and 4-year-old commercial American ginseng (Panax quinquefolium) gardens were monitored from mid-May to September for two growing seasons. Hourly concentrations of airborne A. panax conidia were enumerated using a Burkard volumetric spore sampler. The hourly averages of air temperature, rainfall, leaf wetness, and relative humidity were also collected. Fungicides were not applied. The incidence of leaf blight was assessed in predetermined areas of the monitored gardens. Disease pressure from A. panax was high in 2005 and 2006 and resulted in crop defoliation. Each year, ACCs were detected beginning in late May and continued through the growing season. Daily conidial concentrations followed a diurnal pattern and were greatest during periods of rapidly decreasing relative humidity. Relative humidity was negatively correlated to hourly ACCs. Each year, hourly ACCs were negatively correlated to leaf wetness and rainfall. A positive correlation was detected for hourly ACCs following $16 \mathrm{~h}$ or more of rainfall. A significant correlation was observed between hourly ACCs and temperature.
\end{abstract}

American ginseng (Panax quinquefolium) is a perennial herb grown primarily for the medicinal properties of its root (22). Currently, more than $95 \%$ of the cultivated commercial ginseng in the United States is grown in Wisconsin (1). Cultivated ginseng is grown on a raised plant bed under a tree or black woven polypropylene canopy (22). The shade required by the crop and dense plant spacing create a microclimate with limited air movement and extended leaf wetness periods. In Michigan and Wisconsin, the annual growing season for ginseng occurs over 5 months, with plant emergence beginning in May.

Alternaria blight, incited by Alternaria panax Whetzel, is the most common disease of ginseng throughout the world including Alberta, Canada $(3,4)$, Asia (31), West Virginia (29), North Carolina (7), Michigan (11,12), Oregon, and Washington (24). This disease is a yearly problem for ginseng growers in Wisconsin and can be especially destructive, causing rapid defoliation and plant death (11-13,21).

Typical Alternaria foliar blight symptoms include circular to irregular necrotic lesions, 2 to $20 \mathrm{~mm}$ in diameter. The le-

Corresponding author: Mary Hausbeck

E-mail: hausbec1@msu.edu

Accepted for publication 7 August 2009.

doi:10.1094/PDIS-93-12-1311

(C) 2009 The American Phytopathological Society sions have a dark brown margin and a yellow-green halo (21). Elongated lesions (15 to $45 \mathrm{~mm}$ in length) may also develop on the stem and cause girdling (2). Infected drupes may develop a water-soaked appearance followed by the development of gray mycelium and pathogen sporulation $(11,12)$. Infection of the root by $A$. panax is rare (21); however, root weight can be reduced when blighting of the leaves and stem causes premature defoliation (2).

A. panax conidia may be produced in short chains of two to three spores, but spores more commonly are borne singly $(2,31)$. Although the morphology of $A$. panax conidia is variable (5), conidia are typically 150 to 160 by 12 to $20 \mu \mathrm{m}$ (2) with vertical (one or two) and transverse (nine to 11) septa (23) and are obclavate. Conidia are disseminated via wind, rain, or splashing water (27). A. panax can survive as conidia or as mycelium in infected plant residue, or in and on seeds (16). Lesion development and conidial production can occur in 5 to 7 days under favorable conditions (31). Optimal conidial production and mycelial growth occur with temperatures ranging from 18 to $25^{\circ} \mathrm{C}$ and 24 and $27^{\circ} \mathrm{C}$, respectively $(2,5,6,31)$. Specific leaf wetness parameters required for $A$. panax to infect and produce conidia and mycelia are unknown.

A. panax conidia may overwinter in mulch and crop debris providing initial inoculum for emerging crops in the spring $(12,25)$. A layer of straw mulch $(15 \mathrm{~cm}$ in thickness) generally is applied to ginseng beds immediately following seeding and reapplied throughout the crop production cycle as needed. In winter, straw mulch can prevent temperatures from dropping below the freezing point of the roots (around $-10^{\circ} \mathrm{C}$ ), and in summer it keeps soil temperatures 5 to $10^{\circ} \mathrm{C}$ below that of an unshaded, grassy area (28). Mulch also eliminates the need for irrigation, as it prevents excessive moisture loss from the soil throughout the season (28). Despite these benefits, the use of straw mulch can also be problematic, as A. panax mycelium can spread from plant to plant through the mulch; the pathogen may also spread through the soil as a saprophyte until it contacts the ginseng host $(2,11,16)$. Ginseng growers practice a no-till cultivation system; mulch and plant debris are not removed during the life of the crop ( $\geq 3$ years). Over time, infected ginseng plant tissue can become integrated into the plant beds. Currently, there are no practical methods to reduce $A$. panax inoculum overwintering on the mulch or on infected crop residue (16).

In the absence of effective treatments for Alternaria blight, growers could potentially lose $\$ 13,930 /$ ha in root revenue due to repeated crop defoliation (12). Since $A$. panax also infects drupes, seed may be threatened. With an average seed yield of $337 \mathrm{~kg} / \mathrm{ha}$, growers could lose an additional \$18,537/ha (current market value $\$ 55 / \mathrm{kg}$ ) due to Alternaria blight (12).

Cultural strategies to manage Alternaria blight include increasing plant spacing to enhance air circulation, removing infected foliage, and replacing straw mulch in affected areas (7). Unfortunately, these strategies are not practical and would not preclude the reintroduction of inoculum via air currents. The use of biocontrols as alternatives to traditional fungicides has also been considered for Alternaria blight management. Burkholderia cepacia AMMD (Pseudomonas cepacia strain AMMD) was found to effectively inhibit Alternaria blight under growth chamber conditions. However, the biocontrol agent did not adequately reduce disease under field conditions due to poor survival on leaf surfaces $(15,19,20)$.

Currently, growers rely on fungicides to protect their crop from Alternaria blight (11). Growers must apply fungicide sprays judiciously during the relatively long growing season of May through September to protect the crop and comply with product labels. Currently, azoxystrobin and pyraclostrobin are relied upon in disease 
management programs $(11,12)$. Strobilurin fungicides must be used in alternation with protectant fungicides (i.e., mancozeb, copper, or chlorothalonil) to delay the development of pathogen resistance (11).

To support the development of new management strategies that are less dependent on fungicides, additional epidemiological information for A. panax is needed. Ginseng growers would like to know when fungicide applications should be initiated in the spring and which weather parameters increase airborne conidial concentrations (ACCs). The objectives of this study were to determine (i) when airborne inoculum is available each season, and (ii) which weather factors influence ACCs.

\section{MATERIALS AND METHODS}

Plot establishment. Field studies were conducted in commercial cultivated gin- seng gardens located in Marathon County, WI. Gardens were established from stratified seed which were broadcast planted into 1.5-m-wide raised and sloped plant beds with a peak height of $30 \mathrm{~cm}$. Ginseng seeds were not planted on the lower portion $(20 \mathrm{~cm})$ of the beds. After seeding, the entire plant bed was covered with $15 \mathrm{~cm}$ of straw mulch. Each year, woven polypropylene panels providing $80 \%$ shade were suspended via 2 - to $3-\mathrm{m}$ posts over the plant beds to mimic woodlot conditions. Weeds were pulled by hand.

Two gardens were monitored for Alternaria blight symptoms and airborne $A$. panax conidia. Garden A (3-year-old planting) was monitored from 24 May to 22 August in 2005. Garden B was monitored as a 3-year-old garden (2005) from 26 May to 9 September and as a 4-year-old garden (2006) from 25 May to 30 August. Gardens were divided in half, resulting in approximately 1.6 ha for disease monitoring and spore trapping. Fungicides were applied to the western half of the ginseng gardens according to commercial standards. A 2.2-m nonsprayed buffer was maintained between the eastern and western garden halves. Fungicides were not applied to the eastern half of gardens where monitoring occurred.

Disease incidence. Within the eastern half of the monitored ginseng gardens, four plant bed sections (3 $\mathrm{m}$ in length) were randomly selected prior to the start of spore trapping for disease monitoring. Each bed section contained approximately 250 plants. The number of plants with one or more lesions was determined in each plant bed section. Disease incidence was assessed three times during the 2005 growing season and every other week in 2006.

Weather monitoring. Hourly measurements of air temperature and relative
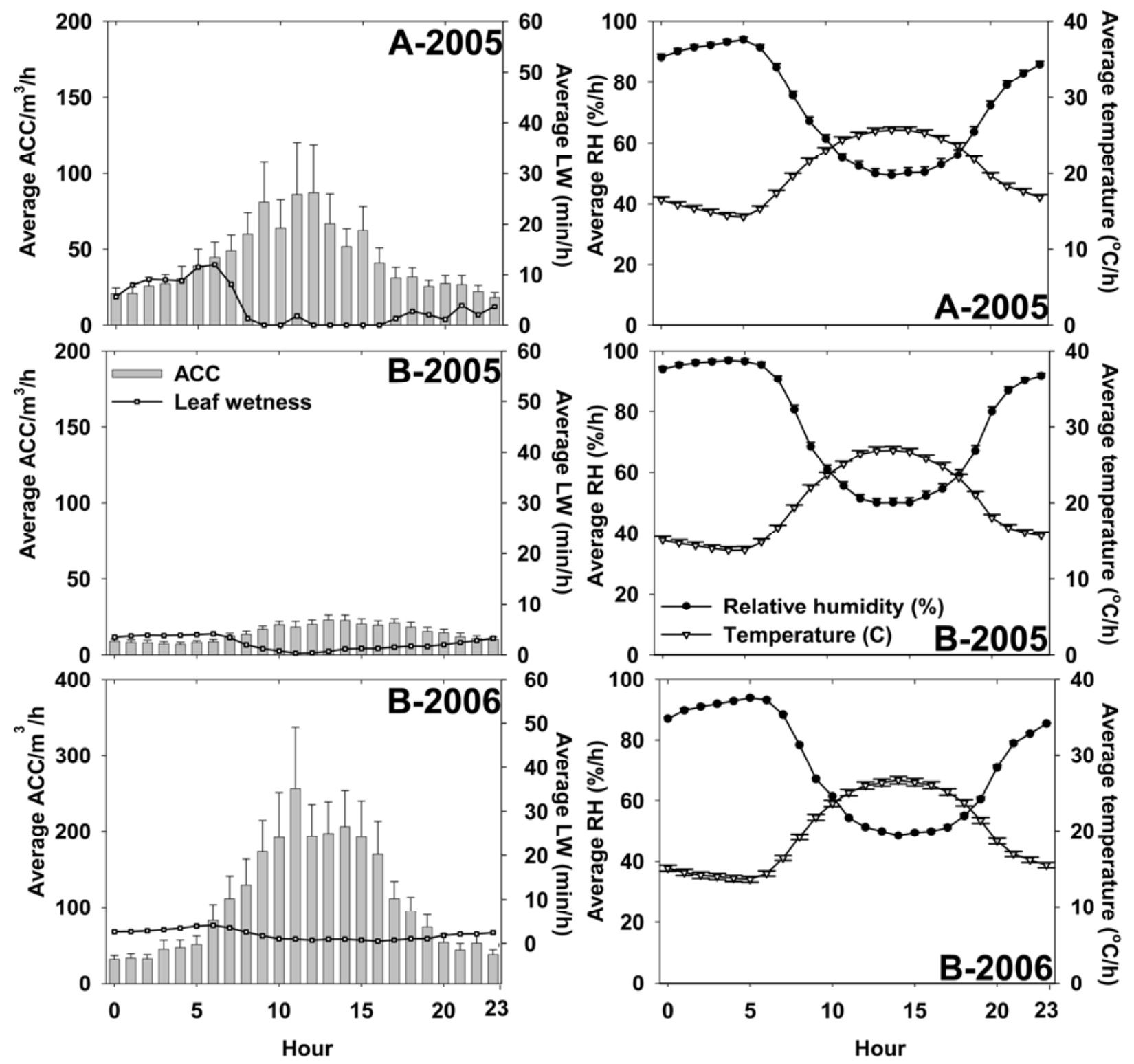

Fig. 1. Hourly averages for Alternaria panax airborne conidial concentrations (ACCs), leaf wetness (LW), relative humidity (RH), and temperature in commercial Wisconsin ginseng gardens A-2005, B-2005, and B-2006. 
humidity were recorded using a data recorder (Watchdog series 450, Spectrum Technologies, Inc., Plainfield, IL). A Watchdog leaf wetness sensor (Spectrum Technologies) was placed at a $45^{\circ}$ angle facing north within the upper $25 \%$ of the ginseng canopy. Moisture occurring for a period greater than $1 \mathrm{~min} / \mathrm{h}$ was recorded. Rainfall was measured hourly using a tipping-bucket rain collector (series 3554WD, Spectrum Technologies). In each garden, environmental monitoring equipment was placed within $1.5 \mathrm{~m}$ of the spore trap. Sensor positions were adjusted periodically as needed. Weather data were downloaded weekly to a laptop computer using commercially available software (Specware 6.01 and 7.01, Spectrum Technologies).

Inoculum availability and airborne concentrations. Concentrations of airborne A. panax conidia were monitored each growing season from 2005 to 2006 using a 7-day volumetric spore sampler (Burkard Scientific, Uxbridge, UK). Monitoring began in May (prior to the development of Alternaria blight symptoms) and concluded in August or September. One spore trap per garden was placed within the plant sections monitored for disease incidence. Spore traps were operated at a flow rate of 10 liter/min, and the orifice was free to move with changing wind direction. The orifice height was maintained 10 to $15 \mathrm{~cm}$ above the canopy. Conidia were collected on melinex tape (Burkard Scientific) coated with an adhesive mixture of petroleum jelly and paraffin $(9: 1, \mathrm{wt} / \mathrm{wt})$ after heating to $60^{\circ} \mathrm{C}$ and cooling overnight before being dissolved with sufficient toluene to give a viscous consistency. Prior to petroleum jelly and paraffin coating, the melinex tapes were coated with a polyvinyl alcohol (Airvol/Gelvatol, grade 603, Burkard Scientific) and phenol mixture ( $35 \mathrm{~g}$ polyvinyl alcohol, $25 \mathrm{ml}$ glycerol, $50 \mathrm{ml}$ distilled water, heated to $40^{\circ} \mathrm{C}$ to combine, then cooled to $23^{\circ} \mathrm{C}$ before adding $2 \mathrm{~g}$ of phenol) and allowed to dry overnight at $23^{\circ} \mathrm{C}$. Prepared tapes were maintained at $23^{\circ} \mathrm{C}$ until use.

Tapes were removed from the spore trap weekly and cut into 48-mm lengths and scored using a razor blade at 2-mm intervals corresponding to a 24-h day. Tape sections were mounted onto $3 \times 2 \mathrm{~cm}$ glass slides and stained with aniline blue $(0.14$ $\mathrm{mg}$ aniline blue, $20 \mathrm{ml}$ distilled water, 15 $\mathrm{ml}$ glycerol, $10 \mathrm{ml}$ of $85 \%$ lactic acid). Slides were covered with $22 \times 50 \mathrm{~mm}$ coverslips and sealed using Cytoseal (Richard-Allan Scientific, Kalamazoo, $\mathrm{MI})$. Mounted slides were allowed to dry at $23^{\circ} \mathrm{C}$ for at least $24 \mathrm{~h}$ before microscopic observation at $\times 200$.

Conidia were counted using a compound light microscope. A. panax was identified based on morphological characters (2,23). Occasionally, conidia of $A$. alternata (20 to $63 \mu \mathrm{m})$ and A. solani (150 to $300 \mu \mathrm{m})$ (26) were observed but were not included in hourly conidial counts. Hourly conidial concentrations were converted to numbers of conidia per cubic meter of air sampled per hour. To eliminate zeros within the data set, 1 was added to each hourly count.

Statistical analysis. Data were first inspected visually by plotting ACC values against temperature $\left({ }^{\circ} \mathrm{C}\right)$, relative humidity
(\%), rainfall, and leaf wetness $(\mathrm{min} / \mathrm{h})$ within each 24 -h period corresponding to 0000 to $2300 \mathrm{~h}$ for each garden location. This allowed us to identify positive or negative associations among variables. Visual correlations were verified using PROC CORR (SAS Institute Inc., Cary, NC) to determine correlation coefficients among hourly ACC and weather parameters (10).
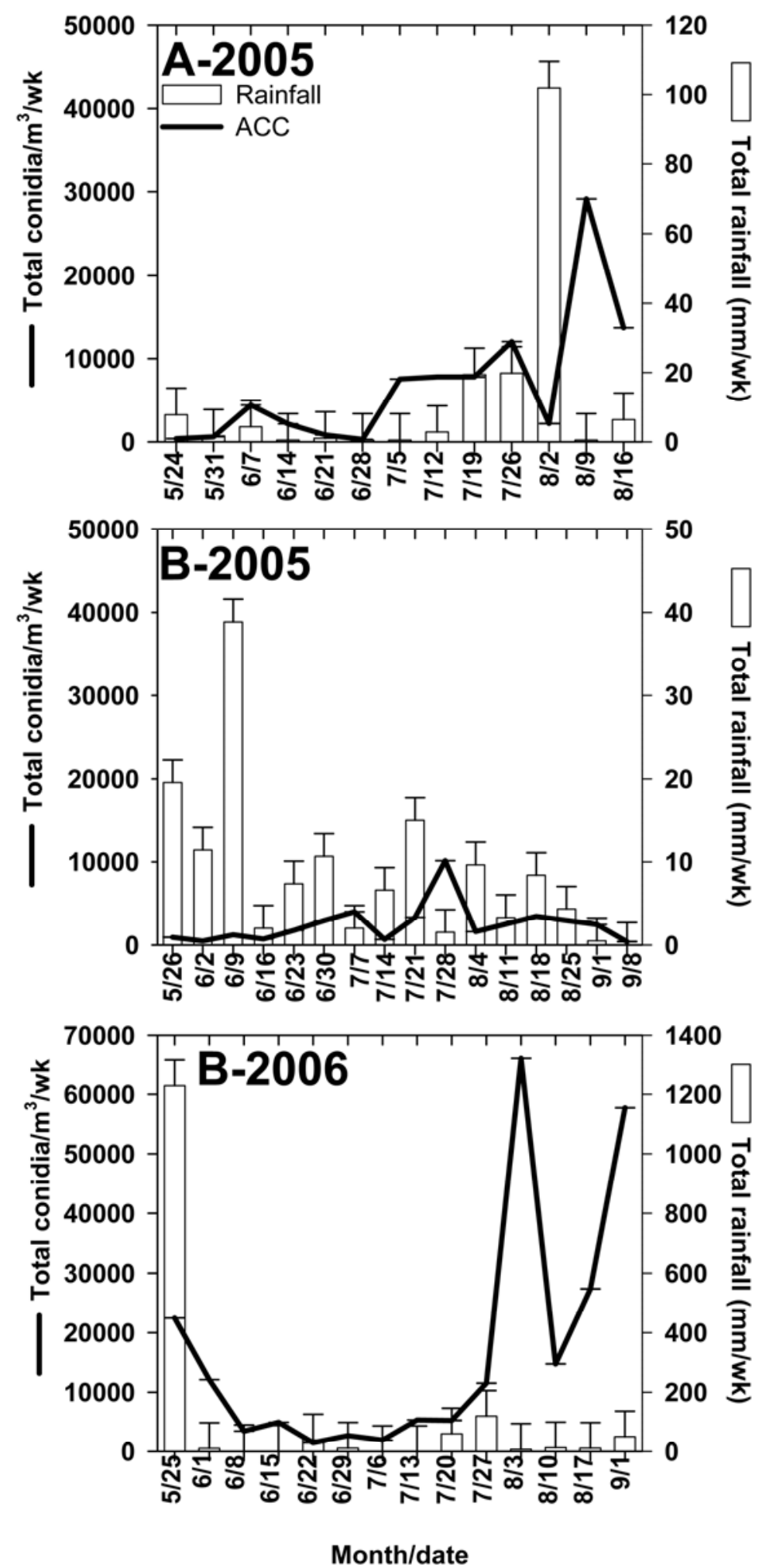

Fig. 2. Weekly (wk) totals for rainfall and Alternaria panax airborne conidial concentrations (ACCs) as observed in commercial Wisconsin ginseng gardens A-2005, B-2005, and B-2006. 
Regression analysis was performed using the PROC MIXED (SAS) to investigate the effect of single and two-factor interactions between weather parameters on hourly ACC values for all gardens. ACC values were regressed on temperature, relative humidity, leaf wetness, temperature $\times$ leaf wetness, and relative humidity $\times$ leaf wetness. Residuals from the regression model were evaluated for normality. Time series analysis procedures (PROC ARIMA, SAS) were used when residuals were dependent. Hourly average ACC data were differenced at lag 1 so that the data series was stationary. For each garden, ARMA models were chosen based on minimum Akaike's Information Criterion (AIC) and Schwarz's Bayesian Criterion (SBC) values.

\section{RESULTS}

Conidial availability, diurnal pattern, and airborne concentrations. Each year, ACCs were detected at the onset of spore trapping and occurred daily throughout the monitoring period. In 2005, ACCs during the first week of monitoring were $<1,000 / \mathrm{m}^{3} / \mathrm{h}$, whereas in 2006 the ACCs were $>1,000 / \mathrm{m}^{3} / \mathrm{h}$. When hourly ACCs were averaged over the monitoring periods, peaks occurred at $1100 \mathrm{~h}$ for garden B-2006 (257 conidia $/ \mathrm{m}^{3} / \mathrm{h}$ ), $1200 \mathrm{~h}$ for garden A-2005 $\left(87 \mathrm{conidia} / \mathrm{m}^{3} / \mathrm{h}\right)$, and $1300 \mathrm{~h}$ for garden B2005 (23 conidia $\left./ \mathrm{m}^{3} / \mathrm{h}\right)$. Relatively few conidia were trapped between $0000 \mathrm{~h}$ and $0500 \mathrm{~h}$, with an average of 26,8 , and 44 conidia $/ \mathrm{m}^{3} / \mathrm{h}$ in garden A-2005, B-2005, and B-2006, respectively (Fig. 1).

ACCs and weather effects. Weekly rainfall averaged $12.9,9.9$, and $111.0 \mathrm{~mm}$ for gardens A-2005, B-2005, and B-2006, respectively (Fig. 2). Average hourly rainfall in gardens A-2005 and B-2006 was negatively correlated with hourly ACC values (Table 1). A positive correlation was observed for ACCs occurring $16 \mathrm{~h}$ or more after rainfall was detected. Across all gardens monitored, the highest weekly ACCs were observed during the latter portion of each growing season (e.g., July, garden B2005; August, gardens A-2005 and B2006) and typically were preceded by rainfall events (Fig. 2). Leaf wetness was detected and occurred with a diurnal periodicity in gardens A-2005 and B-2005 (Fig. 1). Within the 4-year-old ginseng garden (B-2006), leaf wetness did not fluctuate as observed in the 3-year-old gardens (Fig. 1). Hourly ACC values were negatively correlated to leaf wetness in 2005 and 2006 (Table 1).

Within each 24-h period, ACCs peaked during periods of decreasing (20 to $80 \%$ ) relative humidity for 2005 and 2006. Relative humidity was negatively correlated to hourly ACCs; each year the correlation was significant (Table 1). Temperature was positively correlated to ACCs and was significant each year (Table 1). Temperatures between 18 and $25^{\circ} \mathrm{C}$ were most common during all of the monitoring periods. Temperatures rarely fell below $10^{\circ} \mathrm{C}$, with fewer than $10 \mathrm{~h} /$ week on average recorded. Temperatures exceeded $25^{\circ} \mathrm{C}$ each year, with an average of 19 to 24 $\mathrm{h} /$ week observed. The highest hourly temperature recorded in each garden was $34.5^{\circ} \mathrm{C}$ (A-2005), $36.6^{\circ} \mathrm{C}$ (B-2005), and $44.4^{\circ} \mathrm{C}$ (B-2006).

Regression analysis of $A$. panax conidial concentrations against temperature, leaf wetness, and relative humidity was described by the model $(-633.24+$ garden effect) +5.0365 (relative humidity) + 23.7799 (temperature) - 45.2915 (leaf wetness) +0.3027 (relative humidity $\times$ leaf wetness) +1.17722 (temperature $\times$ leaf wetness). Standard errors and $P$ values for terms in the regression model are presented in Table 2. Residues for garden A2005, B-2005, and B-2006 were analyzed using ARIMA models $(0,1,0),(2,1,1)$, and $(0,1,1)$, respectively (Table 3$)$. The effect of temperature, leaf wetness, and the cross interactions of temperature $\times$ leaf wetness and relative humidity $\times$ leaf wetness were significant to the model (Table 2).

Disease incidence. Each year, disease increased throughout the growing season, resulting in significant levels of foliar blighting (Fig. 3). The first Alternaria leaf blight lesions were observed on the foliage on 24 and 20 June of 2005 and 2006, respectively. A significant correlation $(P=$ 0.0048 ) between weekly ACCs and plant disease incidence was observed (Fig. 3). Commonly, high levels (85\%) of crop defoliation were observed in early August. By the end of the monitoring period, many of the garden sections were completely defoliated.

\section{DISCUSSION}

Ginseng growers are interested in adopting integrated pest management to reduce

Table 2. Parameter estimates, standard errors, and $P$ values for effects in regression analysis describing the relationship between airborne Alternaria panax conidial concentrations, temperature, relative humidity, and leaf wetness

\begin{tabular}{lccc}
\hline Effect $^{\mathbf{a}}$ & Estimate & Standard error & $\boldsymbol{P}$ value \\
\hline Intercept & -633.24 & 369.13 & 0.0912 \\
Garden A-2005 & -84.8388 & 18.1173 & $<0.0001$ \\
Garden B-2005 & -138.84 & 9.7343 & $<0.0001$ \\
Garden B-2006 & 0 & - & - \\
Temperature & 23.7799 & 9.7751 & 0.0178 \\
Relative humidity & 5.0365 & 2.5529 & 0.0529 \\
Leaf wetness & -45.2915 & 19.2453 & 0.0217 \\
Temperature $\times$ leaf wetness & 1.1772 & 0.4871 & 0.0186 \\
Relative humidity $\times$ leaf wetness & 0.3027 & 0.1272 & 0.0204 \\
\hline
\end{tabular}

${ }^{a}$ Values were obtained using PROC MIXED (SAS, Cary, NC).

Table 3. Estimates, standard errors, and $P$ values for residues following regression modeling as determined by ARIMA ${ }^{\mathrm{a}}$

\begin{tabular}{lccc}
\hline Effect & Estimate & Standard error & $\boldsymbol{P}$ value \\
\hline $\begin{array}{l}\text { Garden A-2005 } \\
\text { Residue mean }\end{array}$ & 0.17558 & 2.46271 & \\
Garden B-2005 & & & 0.9438 \\
Residue mean & 0.31689 & 2.33803 & 0.8936 \\
Auto regressive & 0.47847 & 0.31797 & 0.1488 \\
Moving average & 1.03274 & 0.24537 & 0.0005 \\
Garden B-2006 & & & \\
$\quad$ Residue mean & 1.14591 & 3.00563 & 0.7068 \\
Moving average & 0.54076 & 0.18478 & 0.0081 \\
\hline
\end{tabular}

a ARIMA models $(0,1,0),(2,1,1)$, and $(0,1,1)$ were for residue analysis in gardens A-2005, B-2005, and B-2006, respectively. Significant effects occur with $P<0.005$.

Table 1. Correlation coefficients between hourly airborne Alternaria panax conidial concentrations and hourly weather parameters in commercial Wisconsin ginseng gardens monitored in 2005 and 2006

\begin{tabular}{|c|c|c|c|c|c|c|c|c|}
\hline \multirow{3}{*}{$\frac{\text { Garden-year }}{\text { A-2005 }}$} & \multicolumn{8}{|c|}{ Weather parameters ${ }^{\mathrm{a}}$} \\
\hline & \multicolumn{2}{|c|}{ Temperature } & \multicolumn{2}{|c|}{ Relative humidity } & \multicolumn{2}{|c|}{ Rainfall } & \multicolumn{2}{|c|}{ Leaf wetness } \\
\hline & 0.59060 & $(0.0024)$ & -0.56871 & $(0.0037)$ & -0.26154 & $(0.2179)$ & -0.42341 & $(0.0439)$ \\
\hline B-2005 & 0.98220 & $(<0.0001)$ & -0.97809 & $(<0.0001)$ & 0.51047 & $(0.0108)$ & -0.93043 & $(<0.0001)$ \\
\hline B-2006 & 0.85860 & $(<0.0001)$ & -0.79165 & $(<0.0001)$ & -0.64149 & $(0.0007)$ & -0.66561 & $(0.0004)$ \\
\hline
\end{tabular}

a Values within parentheses indicate significant correlation $(P \leq 0.05)$. 
fungicide use. To this end, we determined when conidia of $A$. panax are available during the growing season and the weather factors that influence ACCs. Airborne $A$. panax conidia were detected at the onset of the growing season, prior to the development of lesions, suggesting that ginseng growers should initiate fungicide sprays immediately upon plant emergence, especially in conjunction with rainfall events. Currently, many growers initiate fungicide sprays early in the season, but previously, it was not known whether this practice was justified. Also, the detection of conidia throughout the growing season into late August and early September indicates that growers should consider continuing fungicide sprays through September into midOctober for gardens that are not being currently harvested.

Peaks of airborne A. panax conidia in ginseng gardens were correlated with specific weather factors. ACCs were greatest during periods of reduced relative humidity. While conidia were detected during periods of high relative humidity, concentrations were low and a significant negative correlation was found. This suggests that conidia of $A$. panax are not actively released under high humidity conditions. The reduced ACCs during rain events could be attributed to rain scrubbing from the atmosphere (9). Despite a negative correlation between hourly rainfall and ACCs, a positive correlation was detected for ACCs following $16 \mathrm{~h}$ or more after a rainfall event. Rain may temporarily remove conidia from the air, but the coincident leaf wetness period provides favorable conditions for sporulation (14). Optimal conidial production of A. panax occurs with temperatures ranging from 18 to $25^{\circ} \mathrm{C}(2,31)$. In our study, significant ACCs were observed within that range and $\geq 25^{\circ} \mathrm{C}$.

Similar correlations between ACCs and weather parameters observed in our study have been reported for other Alternaria spp. A. solani conidia in controlled environmental chambers were released with sudden increases or decreases in relative humidity, vibration, and rain events (8). Conidia of $A$. tenuis on banana are released during a shift from wet to dry (18). During surface drying, air bubbles are formed on conidial chains of A. tenuis, causing them to twist and resulting in the release of conidia (18). Conidia of $A$. tenuis are also released following both an increase and a decrease in relative humidity (17). Conidia of A. alternata on tangerine were similarly released following sudden increases or decreases in relative humidity and with simulated rainfall events (30). While moisture is important for sporulation of Alternaria, most Alternaria spp. including $A$. panax are able to survive in dry conditions $(27,30,31)$.

The correlation between weather variables and ACCs is critical to the develop- ment of disease models and management. Recently, the disease forecasting system TOM-CAST was evaluated as a tool for timing fungicide sprays for Alternaria blight in ginseng gardens (14). TOMCAST, used for the management of $A$. solani, prompts fungicide applications at specific disease thresholds by calculating daily disease severity values (DSVs) based on cumulative hours of leaf wetness and temperature. In evaluating TOM-CAST using a 10- or 15-DSV program to prompt fungicide applications, neither was able to adequately protect the foliage and seed compared to 7-day spray programs (14). Utilizing lowered DSVs would likely result in a spray schedule with similar num- bers of applications as a 7-day program. It is possible that other factors, such as the level of overwintering inoculum, may affect ACCs. Also, the biology of A. panax and its response to temperature ranges may differ from the other pathogens where TOM-CAST has been successfully used.

Temperatures considered in the TOMCAST forecaster range from 13 to $29^{\circ} \mathrm{C}$ and are based on formation of $A$. solani conidia and conidiophores. In our study, temperature was positively correlated with ACCs; garden temperatures were commonly between 18 and $25^{\circ} \mathrm{C}$. With the use of a black polypropylene canopy, temperatures within the ginseng gardens occasionally exceeded $29^{\circ} \mathrm{C}$. Future studies with
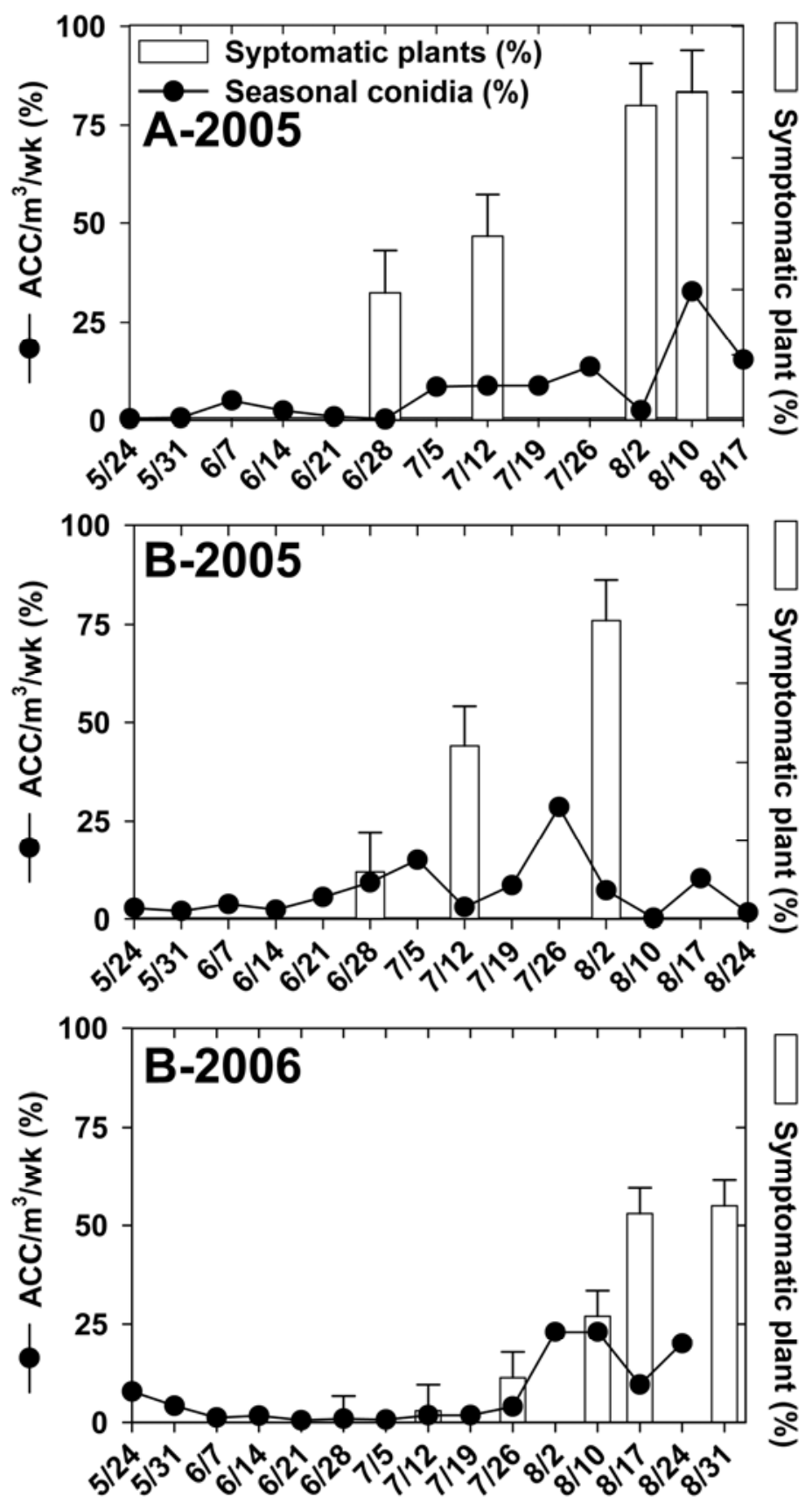

Fig. 3. Percentage of plants with Alternaria panax symptoms and seasonal airborne conidial concentrations (ACCs) per week (wk) observed in ginseng gardens A-2005, B-2005, and B-2006. 
TOM-CAST for use within ginseng gardens could include a broader temperature range.

Leaf wetness is a common and important component of disease models and forecasters (30). The leaf wetness sensor in our study was placed within the top $25 \%$ of the canopy, $25 \mathrm{~cm}$ from the bed gutter which is along the top ridge of the plant bed. The detection of leaf wetness may be compromised at this location since air flow may be greater here than at other locations along the plant bed (e.g., near the bed gutter). Future studies could incorporate an additional leaf wetness sensor along the side of the ginseng bed, where the plant canopy tends to remain wet longer due to limited air movement. Additional studies using controlled environmental chambers to analyze conidial response to weather parameters could be conducted to further refine disease models and forecasting programs. In particular, determining leaf wetness parameters for A. panax and confirming the temperature ranges for conidial sporulation and survival is important. Assessing the effect of canopy density among 2- to 4-year-old ginseng crops on pathogen sporulation and disease development may also be helpful.

\section{ACKNOWLEDGMENTS}

This research was supported by the USDA Cooperative State Research, Education, and Extension Service Pest Management Alternatives Program under Award No. 2003-34381-13522. We would like to thank D. Reif, P. D. Clark, B. R. Harlan, and S. Linderman for technical assistance, and W. Wang for statistical assistance. We appreciate research samples, plots, and the collaboration of the Baumanns, P. Hsu, and C. Untiedt in support of this research.

\section{LITERATURE CITED}

1. Adam, K. L. 2004. Ginseng, goldenseal and other native roots. Horticulture Technical Note. ATTRA Publ. no. IP115.

2. Brammall, R. 1994. Ginseng. Pages 294-295 in: Diseases and Pests of Vegetable Crops in Canada. R. J. Howard, J. A. Garland, and W. L. Sutton, eds. Phytopathol. Soc. Entomol. Soc. Can., Ottawa, ON, Canada.

3. Chang, K. F., Howard, R. J., Gaudiel, R. G., and Hwang, S. F. 1997. The occurrence of gin- seng diseases in Alberta in 1996. Can. Plant Dis. Surv. 77:78-80.

4. Chang, K. F., Howard, R. J., Gaudiel, R. G., Hwang, S. F., and Blade, S. F. 1998. Diseases of ginseng in Alberta in 1997. Can. Plant Dis. Surv. 78:89-91.

5. CSL. 2006. Pest risk analysis for Alternaria panax. Summary pest risk analysis for PHSI interceptions. Sand Hutton, UK. Online publication.

6. David, J. C. 1988. Alternaria panax. Descriptions of pathogenic fungi and bacteria. No. 955. Mycopathologia 103(2):105-124.

7. Davis, J., and Shoemaker, P. B. 1999. Ginseng disease control Phytophthora and Alternaria. Ext. Bull. North Carolina State University and A\&T State University.

8. Gottwald, T. R., Trocine, T. M., and Timmer, L. W. 1997. A computer-controlled environmental chamber for the study of aerial fungal spore release. Phytopathology 87:1078-1084.

9. Gregory, P. H. 1973. The Microbiology of the Atmosphere, 2nd ed. Leonard \& Hill, New York.

10. Hatcher, L. 1994. A step-by-step approach to using the SAS system for factor analysis and structural equation modeling. SAS Publishing, Cary, NC.

11. Hausbeck, M. K. 2004. Pest management in the future. A strategic plan for the Michigan and Wisconsin ginseng industry. USDA Regional IPM Centers, Center Products, PMSPs, Ginseng, archived, 04/13/2004. Online publication.

12. Hausbeck, M. K. 2007. Pest management in the future. A strategic plan for the Michigan and Wisconsin ginseng industry. USDA Regional IPM Centers, Center Products, PMSPs, Ginseng, 12/14/2007. Online publication.

13. Hill, S. N., and Hausbeck, M. K. 2008. Evaluation of TOM-CAST in timing fungicide sprays for management of Alternaria blight on American ginseng. Plant Dis. 92:1611-1615.

14. Hirst, J. M., and Stedman, O. J. 1963. Dry liberation of fungus spores by rain drops. J. Gen. Microbiol. 33:335-344.

15. Joy, A. E., and Parke, J. L. 1995. Biocontrol of Alternaria leaf blight on American ginseng by Burkholderia cepacia AMMD. Pages 93-100 in: The Challenges of the 21st Century - Proc. Int. Ginseng Conf., Vancouver, 1994. W. G. Bailey, C. Whitehead, J. T. A. Proctor, and J. T. Kyle, eds. Simon Fraser University, Burnaby, BC, Canada.

16. Laemmlen, F. 2001. Alternaria diseases. Publ. no. 8040. Regents of University of California, Division of Agriculture and Natural Resources.

17. Leach, C. M. 1975. Influence of relative humidity and red-infrared radiation on violent spore release by Drechslera turcica and other fungi. Phytopathology 65:1303-1312.

18. Meredith, D. S. 1963 . Violent spore release in some fungi imperfecti. Ann. Bot. (Lond.) N. S. 27:39-47.

19. Parke, J. L., and Gurian-Sherman, D. 2001 Diversity of the Burkholderia cepacia complex and implications for risk assessment of biological control strains. Annu. Rev. Phytopathol. 39:225-258

20. Parke, J. L., and Joy, A. E. 1994. Patent no. US00536060A. Biological inoculant effective against Alternaria.

21. Parke, J. L., and Shotwell, K. M. 1989. Diseases of cultivated ginseng. University of Wisconsin-Madison. Agric. Exp. Stn. Publ. no. 3465.

22. Pritts, K. D. 1995. Ginseng How to Find, Grow and Use America's Forest Gold. Stackpole Books, Mechanicsburg, PA

23. Pryor, B. 2003. Alternaria online. The University of Arizona, College of Agriculture. Online publication.

24. Putnam, M. L., and du Toit, L. J. 2003. First report of Alternaria blight caused by Alternaria panax on ginseng (Panax quinquefolium) in Oregon and Washington, USA. Plant Pathol. 52:406.

25. Quayyum, H. A., Gijzen, M., and Traquair, J. A. 2003. Purification of a necrosis-inducing, host-specific protein toxin from spore germination fluid of Alternaria panax. Phytopathology 93:323-328.

26. Reis, R. F., de Goes, A., Mondal, S. N., Shilts, T., Brentu, F. C., and Timmer, L. W. 2006. Effect of lesion age, humidity, and fungicide application on sporulation of Alternaria alter nata, the cause of brown spot of tangerine. Plant Dis. 90:1051-1054.

27. Rotem, J. 1994. The Genus Alternaria: Biology, Epidemiology, and Pathogenicity. American Phytopathological Society, St. Paul, MN

28. Schooley, J. 2003. Ginseng Production in Ontario. OMAFRA Ginseng Series. Online publication.

29. Scott, J. A., Rogers, S., Cooke, D., and Fry, B. L. 1995. Woods-grown ginseng. West Virginia Univ. Ext. Serv., Agric., Field Crops. Online publication

30. Timmer, L. W., Solel, Z., Gottwald, T. R., Ibañez, A. M., and Zitko, S. E. 1998. Environmental factors affecting production, release, and field populations of conidia of Alternaria alternata, the cause of brown spot of citrus. Phytopathology 88:1218-1223.

31. Uchida, J. A. 2003. Crop Knowledge Master: Alternaria panax. Extension Entomology and UHCTAHR Integrated Pest Management Program, Manoa, HI. Online publication. 